\title{
PCNX2 Gene
}

National Cancer Institute

\section{Source}

National Cancer Institute. PCNX2 Gene. NCI Thesaurus. Code C148617.

This gene may play a role in Notch signaling, cell cycle regulation and tumorigenesis. 